\title{
Carbohydrate analysis throughout the development of a protein therapeutic
}

\author{
Elizabeth Higgins
}

Received: 15 April 2009 /Revised: 26 June 2009 / Accepted: 23 September 2009 / Published online: 4 November 2009

(C) The Author(s) 2009. This article is published with open access at Springerlink.com

\begin{abstract}
This review discusses the challenges involved in the characterization of the glycosylation of therapeutic glycoproteins. The focus is on methods that are most commonly used in regulatory filings and lot release testing of therapeutic glycoproteins. The different types of assays for carbohydrate analysis are reviewed, including the distinction between assays appropriate for lot release or better suited to testing during early drug development or indepth characterization of the glycosylation. Characteristics of the glycoprotein and production process that should be considered when determining the amount of testing, the number of different methods to employ and when the testing should be performed during development of protein therapeutics is also discussed.
\end{abstract}

Keywords Recombinant proteins · Biotechnology ·

$\mathrm{N}$-linked oligosaccharides · O-linked oligosaccharides .

Monosaccharide composition - Oligosaccharide profiling

A DNA sequence provides all of the information necessary for a cell to produce a recombinant protein with the same amino acid sequence as the native protein but it does not dictate exactly how that protein will be glycosylated. Therefore, using a human DNA sequence does not guarantee that the molecule will be glycosylated as it is when synthesized by our bodies. The peptide sequence may determine where glycosylation is added to the protein but the mix of glycosyltransferases, within the cell the protein is expressed in and even the conditions under which those cells are cultured will determine what oligosaccharide structures are

\section{E. Higgins $(\bowtie)$}

GlycoSolutions Corporation,

One Innovation Dr., Suite 115,

Worcester, MA 01605, USA

e-mail: liz@glycosolutions.com added to the molecule [1-3]. And even though glycosylation is dependent upon the machinery (glycosyltransferases) present, the cells do not add identical oligosaccharide structures to each protein molecule. This means a glycoprotein is always present in many different glycoforms (the same protein molecule with different oligosaccharides).

It is difficult to know a priori what the "correct" glycosylation is for any therapeutic since:

1. There is rarely information on the glycosylation of the human molecule let alone how the glycosylation affects the molecule.

2. The therapeutic is usually delivered from the bloodstream, which might not be where it is normally found in the human body. It is therefore often exposed to different receptors than the native protein.

3. Human proteins are glycosylated in many different ways so there are no rules for what is appropriate "human glycosylation" and

4. The optimal glycosylation for any molecule is often a trade-off since, for example, the ideal glycosylation for efficacy (i.e. receptor binding) might not be ideal for a long half-life in the bloodstream.

Other than choosing an expression system that tends to glycosylate in a certain fashion or has been engineered to glycosylate in a desired manner there is little that can be done to change the glycosylation of the molecule other than limited in vitro modifications.

Although the first two recombinant proteins approved as therapeutics were not glycoproteins (insulin and human growth hormone) about $40 \%$ of the approved therapeutics today are glycoproteins (excluding monoclonal antibodies, see Table 1). Approximately $70 \%$ of the approved therapeutic glycoproteins have been expressed in $\mathrm{CHO}$ cells (Table 1) which means there is now a great deal of 
Table 1 The glycosylation of approved therapeutics

\begin{tabular}{|c|c|c|c|}
\hline Generic Designation & Therapeutic Protein & Expression System & Glycosylation $^{\mathrm{a}}$ \\
\hline Agalsidase alfa & $\alpha$-galactosidase $\mathrm{A}$ & Human cell line & N-links $[5,6]$ \\
\hline Agalsidase beta & $\alpha$-galactosidase $\mathrm{A}$ & $\mathrm{CHO}$ cells & N-links $[5,6]$ \\
\hline Aldesleukin & Interleukin 2 & E. coli & None \\
\hline Alefacept & $\begin{array}{l}\text { The extracellular CD2-binding portion of the human } \\
\text { leukocyte function antigen-3 (LFA-3) linked to the Fc } \\
\text { portion of human IgG1 }\end{array}$ & $\mathrm{CHO}$ cells & N-links [7] \\
\hline Algulcosidase alfa & Acid glucosidase & $\mathrm{CHO}$ cells & N-links $[8,9]$ \\
\hline Alteplase & Tissue plasminogen activator & $\mathrm{CHO}$ cells & N-links $[10-13]$ \\
\hline Anakinra & Interleukin-1 receptor antagonist (IL-1Ra) & E. coli & None \\
\hline Anti-hemophilic factor & Factor VIII & BHK \& CHO cells & $\begin{array}{l}\text { N-links \& O-links } \\
{[14,15]}\end{array}$ \\
\hline Antithrombin alfa & Antithrombin & Transgenic goat's milk & N-links $[16,17]$ \\
\hline Becaplermin & Platelet-derived growth factor & S. cerevisiae & None \\
\hline Calcitonin-salmon & Salmon calcitonin & E.coli & None \\
\hline Chorionic Gonadotropin alfa & Chorionic Gonadotropin & $\mathrm{CHO}$ cells & $\begin{array}{l}\text { N-links \& O-links } \\
{[18-20]}\end{array}$ \\
\hline Darbepoietin alfa & Engineered erythropoietin with 2 extra $\mathrm{N}$-glycans (long-acting) & $\mathrm{CHO}$ cells & $\begin{array}{l}\text { N-links \& O-links } \\
{[21,22]}\end{array}$ \\
\hline Denileukin diftitox & $\begin{array}{l}\text { Diphtheria toxin fragments A and B (Met1-Thr387)-His } \\
\text { followed by the sequences for interleukin-2 (IL-2; Ala1- } \\
\text { Thr133) }\end{array}$ & E.coli & None \\
\hline Dibotermin alfa & Bone morphogenic protein 2 (BMP-2) & $\mathrm{CHO}$ cells & N-links \\
\hline Dornase alfa & Deoxyribonuclease I & $\mathrm{CHO}$ cells & N-links [23] \\
\hline Drotrecognin alfa (activated) & Activated Protein $\mathrm{C}$ & $\begin{array}{l}\text { Human kidney cell line }(293 \\
\text { cells) }\end{array}$ & N-links [24] \\
\hline Epoetin alfa & Erythropoietin & $\mathrm{CHO}$ cells & $\begin{array}{l}\text { N-links \& O-links } \\
{[21,22,25]}\end{array}$ \\
\hline Etanercept & $\begin{array}{l}\text { A dimeric fusion protein consisting of the extracellular ligand- } \\
\text { binding portion of the human } 75 \text { kilodalton (p75) tumor } \\
\text { necrosis factor receptor (TNFR) linked to the Fc portion } \\
\text { of human IgG1 }\end{array}$ & $\mathrm{CHO}$ cells & $\begin{array}{l}\text { N-links \& O-links } \\
\text { [26] }\end{array}$ \\
\hline Factor VIIa & Factor VIIa & BHK cells & $\begin{array}{l}\text { N-links \& O-links } \\
\text { [27] }\end{array}$ \\
\hline Factor VIII & Antihemophilic Factor & $\begin{array}{l}\text { BHK cells \& } \mathrm{CHO} \text { cells \& } \\
\text { animal cell line }\end{array}$ & N-links [28] \\
\hline Factor IX & Factor IX & $\mathrm{CHO}$ cells & $\begin{array}{l}\text { N-links and O-links } \\
\text { [29-31] }\end{array}$ \\
\hline Filgrastim & G-CSF with an N-terminal methionine & E. coli & None \\
\hline Follitropin beta & Follicle-stimulating hormone & $\mathrm{CHO}$ cells & N-links $[32,33]$ \\
\hline Galsulfase & $\mathrm{N}$-acetylgalactosamine 4 sulfatase (Arylsulfatase B) & $\mathrm{CHO}$ cells & N-links [34] \\
\hline Glucagon & Glucagon & S. cerevisiae & None \\
\hline Hepatitis B vaccine & Surface antigen of Hepatitis B & S. cerevisiae & $\begin{array}{l}\text { N-links \& O-links } \\
\text { [35-37] }\end{array}$ \\
\hline Hepatitis B vaccine & $\mathrm{S}$, pre-S and pre-S2 & Murine cell line & $\begin{array}{l}\text { N-links \& O-links } \\
\text { [35-37] }\end{array}$ \\
\hline Hirudin & Hirudin & S. cerevisiae & None \\
\hline Human growth hormone & Human growth hormone & E. coli & None \\
\hline $\begin{array}{l}\text { Human Papilloma (HPV) } \\
\text { Vaccine }\end{array}$ & $\begin{array}{l}\text { Virus-like particles (VLPs) of the major capsid (L1) } \\
\text { protein of HPV Types } 6,11,16 \text {, and } 18\end{array}$ & S. cerevisiae & N-links [38] \\
\hline Hyaluronidase & Human hyaluronidase & $\mathrm{CHO}$ cells & N-links [39] \\
\hline Imiglucerase & $\beta$-glucocerebrosidase & $\mathrm{CHO}$ cells & N-links $[40-42]$ \\
\hline Insulin & Insulin & E. coli and $S$. cerevisiae & None \\
\hline Insulin aspart & Insulin with proline substituted with aspartic acid at B28 & S. cerevisiae & None \\
\hline Insulin detemir & Long-acting insulin analog & S. cerevisiae & None \\
\hline Insulin glargine & $\begin{array}{l}\text { Insulin modified by replacing the asparagine at position } 21 \text { with } \\
\text { glycine and adding } 2 \text { arginines to the } C \text {-terminus of the } B \text { chain }\end{array}$ & E. coli & None \\
\hline Insulin glylisine & Rapid-acting insulin analog & E. coli & None \\
\hline
\end{tabular}


Table 1 (continued)

\begin{tabular}{|c|c|c|c|}
\hline Generic Designation & Therapeutic Protein & Expression System & Glycosylation $^{\mathrm{a}}$ \\
\hline Insulin lispro & Insulin with lysine (B28) and proline (B29) switched & E. coli & None \\
\hline $\begin{array}{l}\text { Interferon-11 (missing } \mathrm{N}- \\
\text { terminal proline) }\end{array}$ & Interferon-11 missing the $\mathrm{N}$-terminal proline & E. coli & None \\
\hline Interferon alfa- $2 \mathrm{a}$ & Interferon alpha-2a & E. coli & None \\
\hline Interferon alfa- $2 b$ & Interferon alpha- $2 b$ & E. coli & None \\
\hline Interferon alfacon-1 & Engineered type-1 interferon & E. coli & None \\
\hline Interferon beta-1a & Interferon beta & $\mathrm{CHO}$ cells & N-links [43-46] \\
\hline Interferon beta- $1 \mathrm{~b}$ & Interferon beta with serine substituted for cysteine at position 17 & E. coli & None \\
\hline Interferon gamma-1b & Interferon gamma & E. coli & None \\
\hline Laronidase & $\alpha$-L-iduronidase & $\mathrm{CHO}$ cells & N-links $[47,48]$ \\
\hline Lenograstim & Granulocyte colony stimulating factor (G-CSF) & $\mathrm{CHO}$ cells & O-links [49] \\
\hline Lepirudin & Hirudi & S. cerevisiae & None \\
\hline Lutropin alfa & Luteinizing hormone & $\mathrm{CHO}$ cells & N-links $[50,51]$ \\
\hline Lyme Disease Vaccine & OspA. Lipoprotein from the surface ofBorrelia burgdorferi. & E. coli & None \\
\hline Mecasermin rinfabate & Complex of rh IGF-1 and IGFBP-3 & E. coli & None \\
\hline Mecasermin & IGF-1 & E. coli & None \\
\hline Moroctocog alfa & Factor VIII with residues744-1637of the B domain deleted & $\mathrm{CHO}$ cells & N-links [28] \\
\hline Nesiritide & Human B-type natriuretic peptide (hBNP) & E. coli & None \\
\hline Octogog alfa & Factor VIII & CHO cells \& BHK cells & N-links [28] \\
\hline Oprelvekin & Interleukin 11 & E. coli & None \\
\hline $\begin{array}{l}\text { Osteogenic protein } 1 \\
\text { (BMP-7) }\end{array}$ & Osteogenic protein 1 (BMP-7) & $\mathrm{CHO}$ cells & N-links [52] \\
\hline Palifermin & Keratocyte growth factor & E. coli & None \\
\hline $\begin{array}{l}\text { Parathyroid hormone } \\
\text { (shortened form) }\end{array}$ & Shortened form of parathyroid hormone & E. coli & None \\
\hline Peginterferon alfa- $2 a$ & Peglylated interferon alpha-2a & E. coli & None \\
\hline Peginterferon alfa- $2 b$ & Pegylated interferon alpha- $2 \mathrm{~b}$ & E. coli & None \\
\hline Pegfilgrastim & Pegylated G-CSF with an N-terminal methionine & E. coli & None \\
\hline Pegvisomant & Pegylated growth hormone receptor antagonist & E. coli & None \\
\hline Protropin & $\begin{array}{l}\text { Human growth hormone with an additional N-terminal } \\
\text { methionine }\end{array}$ & E. coli & None \\
\hline Rasburicase & Urate oxidase & S. cerevisiae & None \\
\hline Reteplase & $\begin{array}{l}\text { Amino acids } 1-3 \text { and } 176-527 \text { of tissue plasminogen } \\
\text { activator }\end{array}$ & E. coli & None \\
\hline Sargramostim & $\begin{array}{l}\text { Granulocyte macrophage colony-stimulating factor (Leu } \\
\text { substitution at position 23) }\end{array}$ & S. cerevisiae & None \\
\hline Semorelin & Human growth hormone-releasing hormone $\left(1-29 \mathrm{NH}_{2}\right)$ & Synthetic peptide & None \\
\hline Somatropin & Human growth hormone & $\begin{array}{l}\text { E. coli, } \mathrm{C} 127 \text { cells and } S \text {. } \\
\text { cerevisiae }\end{array}$ & None \\
\hline Tasonermin & Tumor Necrosis Factor (TNF) alfa-1a & E. coli & None \\
\hline Tenecteplase & Engineered version of tissue plasminogen activator (t-PA) & $\mathrm{CHO}$ cells & N-links $[10-13]$ \\
\hline Teriparatide & Human parathyroid hormone (1-34) & E. coli & None \\
\hline Thyrotropin alfa & Thyroid stimulating hormone & CHO Cells & $\begin{array}{l}\text { N-links }[50,51,53 \\
54]\end{array}$ \\
\hline Vibrio Cholerae Vaccine & Contains cholera toxin $\beta$ subunit & V. cholerae & None \\
\hline
\end{tabular}

${ }^{\mathrm{a}}$ Where possible the references are for glycosylation of the drug, however, this information is not available for many drugs so the references are for general information on glycosylation of the protein

information available on the glycosylation of recombinant proteins expressed in $\mathrm{CHO}$ cells. The glycosylation patterns of different commonly used cell lines is reviewed in Grabenhorst [4]. There are also many groups working at engineering the glycosylation in different expression systems [2]. The goal of these engineering efforts is to improve the consistency, reduce the heterogeneity and/or make it possible to produce specific glycoforms.

Glycosylation can impact the pharmacokinetics, pharmacodynamics and/or efficacy of a glycoprotein therapeutic. It is therefore necessary to analyze the glycosylation on glycoproteins being developed as therapeutics. However, it 
can still be difficult to determine how much glycosylation analysis should be performed at the different stages of development or which assays should be used for the analysis. These issues are addressed in this review.

This topic was last reviewed in 1990 by Michael Spellman [55] when there were very few approved recombinant glycoprotein therapeutics, let alone the prospect of biosimilars or follow-on biologics. The list of approved recombinant glycoprotein therapeutics is now much longer and there is much more known about the glycosylation of recombinant glycoproteins (see Table 1 for a summary) and some of the problems that are likely to arise while developing a glycoprotein therapeutic. There are now more and better analytical tools available for carbohydrate analysis. There may not be a consensus on the best specific methods but certain types of analysis have become the standard for assessing the consistency of glycosylation.

This review will cover N-linked glycosylation (where glycans are attached to asparagine residues in the peptide sequence, sees Figs. 1 and 2) and mucin-type O-linked glycosylation (where GalNAc is attached to serine/threonine residues and then additional monosaccharides may be added to the GalNAc, see Fig. 3). Other types of glycosylation are reviewed by Vliegenthart [56] and Spiro [57].

Due to the wealth of literature already available on monoclonal antibodies (reviewed in [58] and [59]), the focus of this review will be on glycoprotein therapeutics and not monoclonal antibodies. Nonetheless, the strategy and analytical methods discussed in this review do also apply to the characterization of the glycosylation of monoclonal antibodies.

\section{An historical perspective}

The first two glycoproteins approved as therapeutics were tissue plasminogen activator (t-PA) and erythropoietin. The

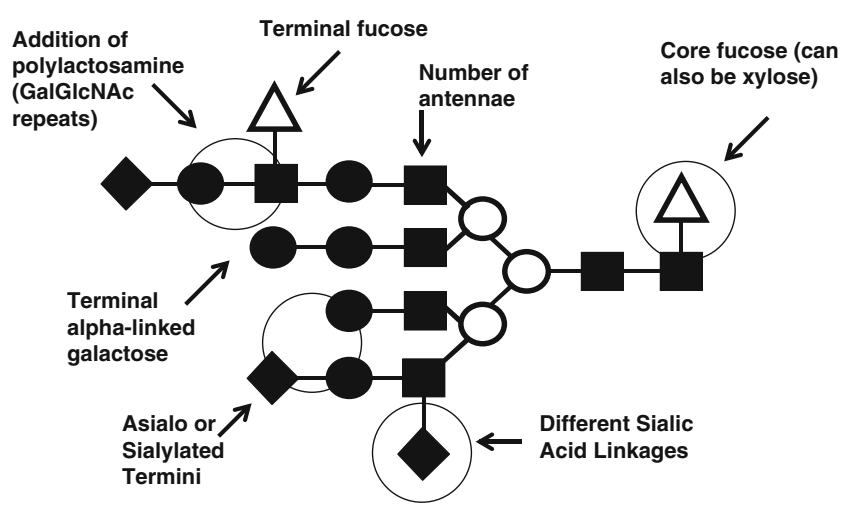

Fig. 1 An imaginary complex N-linked oligosaccharide demonstrating modifications that can occur on these oligosaccharide structures. $\square$ is GlcNAc; $\bigcirc$ is galactose; $\bigcirc$ is mannose, $\triangle$ is fucose and $\square$ is sialic acid
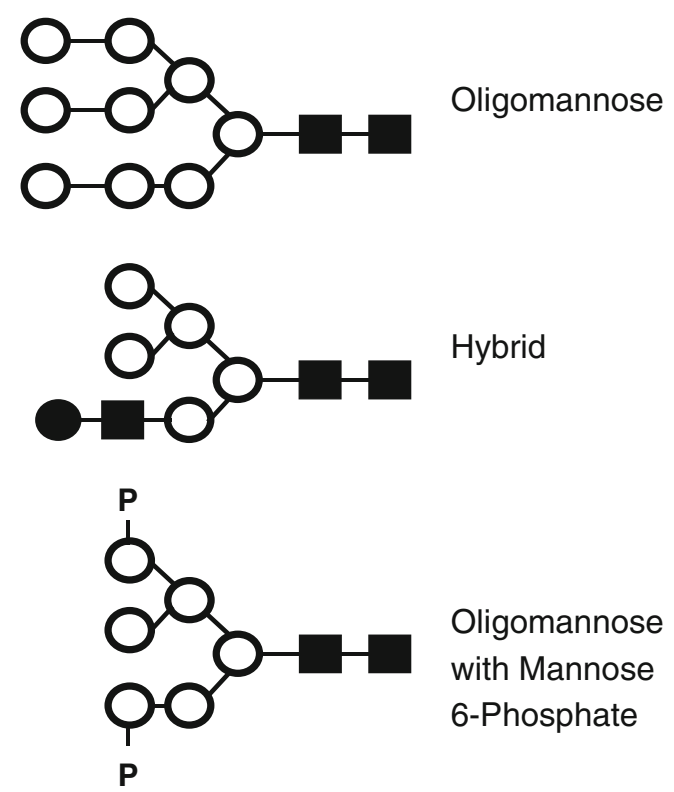

Fig. 2 Oligomannose and hybrid oligosaccharide structures. GlcNAc; is galactose; $\mathrm{O}$ is mannose and $\mathrm{P}$ is phosphate

glycosylation of t-PA was shown to affect its enzymatic activity [60-62] and the plasma clearance of the molecule [63-65]. Glycosylation was also shown to be necessary for the activity [66-68] and plasma clearance of erythropoietin (reviewed by Takeuchi [21]). These two molecules demonstrate how glycosylation can have a significant impact on plasma clearance and why it isn't always easy to predict what impact the glycosylation will have on the plasma clearance of your molecule.

Alteplase (t-PA) has 3 glycosylation sites; one which is glycosylated with oligomannose structures and two that are glycosylated with complex oligosaccharides although one of these is only occupied $50 \%$ of the time [10]. The plasma
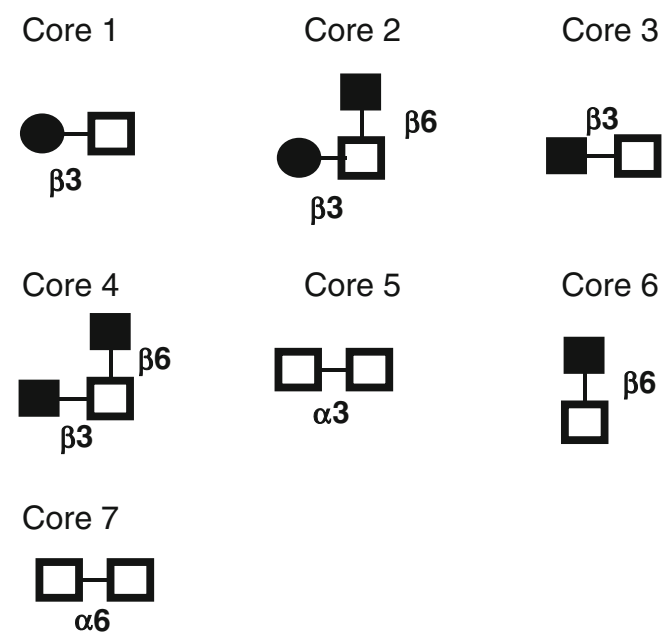

Fig. 3 O-linked oligosaccharide core structures. These structures can be extended, much like N-linked oligosaccharides. $\square$ is GlcNAc; is galactose and $\square$ is GalNAc 
clearance of t-PA is mediated through receptors that bind to the protein and the mannose receptor that binds to the oligosaccharides [69-72]. T-PA binds to the mannose receptor with a higher affinity than other glycoproteins containing oligomannose structures and there is evidence that the underlying protein structure enhances the binding to the mannose receptor [73].

Tenecteplase is an engineered version of t-PA in which the glycosylation site containing oligomannose structures has been removed and a new glycosylation site (which is glycosylated with complex structures) has been added to the molecule. Tenecteplase has a much longer plasma halflife than alteplase and is a good demonstration of how difficult it can be to understand the role that glycosylation plays in plasma clearance. Some of the increase in half-life seen with Tenecteplase can be attributed to the removal of the oligomannose structures (because of clearance by mannose receptors) but not all, since a mutant with only the oligomannose site removed does not have a half-life as long as tenecteplase [74]. A nonglycosylated version of tPA (produced in E. coli) in which a large part of the molecule has been deleted (reteplase) has a similar half-life to tenectaplase [75].

Erythropoietin also has an interesting glycosylation story. Erythropoietin has $3 \mathrm{~N}$-linked oligosaccharides and one O-linked oligosaccharide [22]. Erythropoietin tends to be glycosylated predominantly with triantennary and tetraantennary oligosaccharides, whether it is the natural urinary form or the recombinant expressed in $\mathrm{CHO}$ [76] or BHK cells (reviewed by Takeuchi [21]). Polylactosamine (the repeating disaccharide [3Gal $\beta 1-4 \mathrm{GlcNAc} \beta 1]_{\mathrm{n}}$ that is attached to terminal galactose residues on complex structures) is also commonly seen on the molecule. Polylactosamine is more common on the molecule expressed in $\mathrm{CHO}$ or BHK cells than on the natural urinary form [21]. The glycosylation of erythropoietin has been shown to be necessary for its activity [66-68] as well as its secretion and function [77]. As has been reported for other glycoprotein growth factors [78], EPO binds better to its receptor when the molecule is desialylated, however; the loss of sialic acid results in a dramatic reduction in in vivo activity [79, 80]. Although the loss of in vivo activity in glycoprotein therapeutics is often attributed to the efficient clearance of undersialylated molecules by the hepatic asialo glycoprotein receptor [81], most often the role of carbohydrates in plasma clearance is more complicated than can be explained by the asialoglycoprotein receptor alone. In EPO, branching of the oligosaccharide chains seems to play a role since a version of EPO with more biantennary structures (rather than the typical tetraantennary structures) was shown to clear much faster even though most of its galactose residues were sialylated and it had a three-fold higher in vitro activity [82].
There is a new version of EPO in which two additional $\mathrm{N}$-linked oligosaccharide structures are present [83]. This molecule has been shown to be safe and has a much longer plasma half-life. There have been no reports of patients developing antibodies to this molecule, even though glycosylation sites have been added to the molecule [83].

When the first protein therapeutics were produced the methods used for characterizing their glycosylation came from academic groups that had skillfully worked out ways to identify the oligosaccharide structures on glycoproteins or other glycans. The techniques utilized included FABMS, NMR, lectin blots and columns, multi-dimensional HPLC methods and GC-MS, among others. These techniques had been developed to enable scientists to determine the exact structure of oligosaccharide structures, including the glycan linkages between the monosaccharide units. Although these methods were tremendously important for determining the glycosylation of those first recombinant proteins - these methods did not transfer well to biotechnology laboratories. In biotechnology laboratories the emphasis was more on demonstrating that the glycosylation was consistent batch-to-batch (as opposed to identifying each oligosaccharide on a molecule), and analyzing many samples at once to compare their glycosylation. Data were required quickly and techniques would need to be run by scientists with relatively little experience in carbohydrate chemistry. The first real assays developed for the unique needs of biotechnology came when Hardy and Townsend published their HPAEC methods for a one-dimensional separation of oligosaccharides (now referred to as oligosaccharide profiling) and monosaccharide analysis using an HPLC $[84,85]$ and reviewed in $[86,87]$. The key to these methods was a detector that was sensitive to underivitized carbohydrates (which are very difficult to detect by UV) and a chromatography method that was able to separate oligosaccharides and monosaccharides far better than any previous method. These methods for carbohydrate analysis were the first designed to address the issues unique to biotechnology. Since then, many methods have been developed that work well in the biotechnology laboratory.

\section{A strategy}

Unfortunately, there is no single method that can be used to completely characterize the glycosylation on a molecule and different methods must be employed, depending upon the type of glycosylation on the molecule and the specific information that is required. Oligosaccharides can be analyzed in three different ways: while attached to the protein (peptide mapping and analysis of glycopeptides), after releasing intact from the protein (oligosaccharide 
profiling) or after being broken down into their constituent monosaccharide units (monosaccharide analysis).

The degree to which the glycosylation on the therapeutic is analyzed may vary during drug development. How thorough the characterization of the glycosylation needs to be and how early in drug development it is started should depend upon consideration of factors such as whether the glycosylation is known to have an impact on the efficacy or the pharmacokinetics, any special issues raised by the expression system used to produce the protein, or changes in the expression system that would affect the glycosylation. If specific types of glycosylation are necessary for optimal activity, then the glycosylation may need to be characterized early in development. And conversely, if your expression system might be adding glycosylation that is not ideal or could be a safety concern then this will need to be addressed early in development. If there is any reason to believe that the glycosylation is not consistent, especially if changes in glycosylation are coincident with any changes in the pharmokinetics or activity of your molecule then more detailed analysis may become necessary to understand this relationship.

Unless there is reason to believe that very specific types of glycosylation (i.e. more highly branched complex structures) are required for an efficacious product, regulatory agencies are usually more concerned with demonstrating that the glycosylation is consistent (often referred to as having "consistent heterogeneity") rather than on the identification of all the different oligosaccharides present on the molecule. This is especially true if the role of glycosylation on the function of the glycoprotein is well understood and/or it has been expressed in an expression system where the glycosylation patterns have been well characterized. The heterogeneity in glycosylation profiles of many therapeutics does make it far more challenging to assess whether two different lots of a drug have comparable glycosylation.

It is always wise to monitor the glycosylation for consistency throughout product development to demonstrate that your process produces molecules with consistent glycosylation and for the reassurance that the molecules used in preclinical and clinical work have a similar glycosylation profile to the ultimate molecule headed for the market. Due to this, it is usually wise to begin analyzing glycosylation by the time the first clinical, or even preclinical lots are produced.

Analytical methods used to analyze the glycosylation of therapeutic proteins can be separated into two categories: methods needed to demonstrate the consistency of glycosylation from lot to lot (likely to become release assays, which will need to be validated) and methods used for more in depth analysis of the glycosylation (used to characterize specific critical lots and/or to understand changes in glycosylation patterns, that won't necessarily be validated).

The most common method used for demonstrating the lot-to-lot consistency of glycosylation on a protein therapeutic is oligosaccharide profiling. These methods provide an overview of the heterogeneity of the molecule, can be validated and transferred to a QC setting for release testing and should be very sensitive to changes in glycosylation. These methods can be useful from early in development and it is the most common type of analysis used for lot release-testing to demonstrate the consistency of the glycosylation once a product has been approved. Furthermore, most of these methods can be used to separate oligosaccharide structures for identification or further characterization, when and if this becomes necessary (either by on-line methods or by isolating them and doing further analysis on the fractions). For all of these reasons, oligosaccharide profiling methods are used for most therapeutic glycoproteins starting prior to clinical trials and are usually included as a release test by the time the drug is marketed. Due to the important role that sialic acid has been shown to play in the half-life of protein therapeutics in the bloodstream, sialic acid is often quantified on therapeutics. The efficacy of a drug is also more likely to be affected by differences in sialylation than other modifications in the glycosylation (see Figs. 1, 2 , and 3 for examples of modifications). This makes sialic acid analysis the second most common type of glycosylation analysis for therapeutics and like oligosaccharide profiling, is usually used prior to the start of clinical trials and often becomes a release test by the time the drug is marketed.

Another reason for analyzing the sialic acid on your molecule is to determine whether there is any $\mathrm{N}$ glycolylneuraminic acid (NGNA or NeuGc) present. NeuGc is a sialic acid found in many animal cells (including $\mathrm{CHO}$ cells) that is not found in humans because we lack the enzyme required for its synthesis. Historically, this has created concern over the presence of this sialic acid on therapeutics but it has now been demonstrated that although humans cannot synthesize NeuGc, it is found in normal human tissues [88]. It would appear that humans pick up NeuGc from diet $[88,89]$ and it is incorporated into tissues. In fact, Byres et al. have shown that the presence of this NeuGc on human tissues creates high affinity receptors for a bacterial toxin [90]. It has also been demonstrated that many humans produce antibodies against oligosaccharide structures with terminal NeuGc [91].

Beyond these two analyses there are additional assays used for analyzing glycosylation. Determining whether further analysis is required and which additional methods are employed depends upon the role of glycosylation on 
your molecule and the expression system used. These different methods and the information obtained from them are described in the next section.

\section{Oligosaccharide profiling}

Oligosaccharide Profiling (also referred to as mapping or fingerprinting) is the best method for monitoring the consistency of the glycosylation of your molecule. With this method, oligosaccharides (N-linked and/or O-linked) are released intact from the molecule and separated to create the profile. This profile can be a chromatogram from an HPLC/CE separation, a mass profile generated using mass spectrometry or the pattern of bands generated by gel electrophoresis of oligosaccharides. For a therapeutic, it is most important that the profile is sensitive to changes in glycosylation, especially any changes in glycosylation that are known to affect the safety or efficacy or the molecule. The method must also be robust and reproducible. It is helpful if the same method can be used for routine testing and further characterization/identification of the oligosaccharides (i.e. by isolating the peaks or by on-line mass spectrometric analysis).

$\mathrm{N}$-linked oligosaccharides are most commonly removed enzymatically from glycoproteins using peptide: $\mathrm{N}$-glycosidase F (PNGase F). PNGase F has been shown to release oligomannose, hybrid and complex oligosaccharides from glycoproteins. It will not release oligosaccharides from the asparagine unless both the carboxyl and amino termini are in peptide bonds $[92,93]$. There is also one report in the literature [48] of a bisphosphorylated glycopeptide that was resistant to PNGase F until it was desphosphorylated. PNGase $\mathrm{F}$ will not release any oligosaccharide that contains a fucose linked $\alpha 1-3$ to the GlcNAc bound to the asparagine [94]. Plants and insect cells add fucose in this linkage. N-linked oligosaccharides can also be released by peptide:N-glycosidase A (PNGase A), which releases all classes of oligosaccharides [92, 93]. The different enzymes used to release glycans are reviewed in O'Neill [95].

$\mathrm{N}$-linked oligosaccharides can also be released chemically using hydrazinolysis [96, 97]. This method has not been commonly used since PNGase $\mathrm{F}$ has become commercially available, because of the safety issues created by the chemicals used in this procedure and the complexity of the procedure. $\mathrm{N}$-acetyl and $\mathrm{N}$-glycolyl groups are also lost when oligosaccharides are released by hydrazinolysis $[98,99]$.

For many laboratories, the fastest and easiest way of profiling oligosaccharides is by mass spectrometry, especially MALDI-TOF MS. This method has the advantage of providing more information on the types of oligosaccharide structures present because the masses of the oligosacchar- ides can be matched to possible oligosaccharide structures. There are software packages that can perform this analysis. However, all possible isobaric oligosaccharides (oligosaccharide structures having the same mass) must be carefully considered when matching possible oligosaccharide structures to masses. An understanding of glycosylation pathways, in general and in different expression systems is critical when eliminating impossible or unlikely glycan structures. In early drug development, generating oligosaccharide mass profiles is often the preferred method of oligosaccharide profiling. However, there has been resistance to validating these methods and transferring them into QC laboratories due to concerns over the accuracy of quantification by mass spectrometry (even though it has been demonstrated that it can be used quantitatively [100]), the complexity of the equipment, the volume of data generated and the challenges of data analysis. This has left oligosaccharide mass profiling as an incredibly valuable method during early drug development, when oligosaccharides need to be identified, as an orthogonal method (to HPLC or CE methods) later in development and when critical lots need to be analyzed (for example, process qualification lots). Mass spectrometric methods have been reviewed recently by Wada [100] and Stadlmann [101].

Although electrophoretic methods [102], mass spectrometry $[100,103]$ and $C E[102,104,105]$ are all used for oligosaccharide profiling, HPLC methods have been the most commonly used method for lot release. There are many HPLC separations for $\mathrm{N}$-linked oligosaccharides described in the literature (reviewed in [106]), however, many of them are not all that useful for N-linked oligosaccharide profiling of therapeutic glycoproteins. To be useful for the profiling of therapeutic glycoproteins a method should:

1. Generate a good separation in one dimension (earlier methods separated oligosaccharides based upon one characteristic on one column, then another on a second column).

2. Shifts in the oligosaccharide pattern should be predictive of changes in the glycoform distribution (i.e. changes in size or charge can be inferred from a shift in retention times)

3. Utilize a sensitive method for detection (important since oligosaccharides do not contain good chromophores)

4. Be amenable to further characterization of the oligosaccharides, either by collecting the oligosaccharides for further analysis or by on-line analysis.

Although oligosaccharide profiling by HPLC may not immediately provide many specific details about the glycosylation of the molecule (methods utilizing mass spectrometry are better at this) it is a very sensitive test of lot-to-lot variation in the glycosylation. It is also a relatively simple analysis to perform and a good HPLC profiling 
method can provide important information on consistency even if the identity of the oligosaccharides in each peak is not known. It is possible to develop platform methods that will work well for most glycoproteins without the need for extensive optimization for individual glycoproteins. HPLC profiling data can be collected to demonstrate the consistency of glycosylation early in drug development and then the oligosaccharide peaks in the profile can be identified later in development. It is however, important to choose an oligosaccharide profiling method that has been documented to provide sufficient detail and able to detect relevant changes in glycosylation.

High $\mathrm{pH}$ anion-exchange chromatography (HPAEC) of underivatized oligosaccharides with pulsed-amperometric detection (PAD) was the first oligosaccharide profiling method ([85, 107] and reviewed in [86]) that addressed the needs of monitoring the glycosylation of therapeutic glycoproteins. In this method, oligosaccharides are separated using high $\mathrm{pH}(\mathrm{pH}$ 12). The high $\mathrm{pH}$ converts hydroxyl groups to oxyanions and differences in the interaction of these oxyanions in the oligosaccharides with the anion exchange resin result in differences in the retention times. Although these methods provided very good separations of oligosaccharides they are difficult to work with, because the mobile phases contain a large amount of salt (sodium hydroxide and sodium acetate) which is difficult to remove from isolated oligosaccharides. Different oligosaccharides respond differently to this form of detection making quantification, or even relative quantification of different oligosaccharides impossible. Although recent advances in the technology have made this less of an issue, the gold electrode gets fouled over time, which affects the response and creates issues with day-to-day reproducibility.

Separations on amide or amino columns are now available that are as sensitive to changes in the oligosaccharide structure as the HPAEC methods and these have become the method of choice for many laboratories. These separations use a combination of both normal phase and anion-exchange separations [108-112]. Weak anionexchange methods were historically used to separate oligosaccharides into charged groups, but they were unable to separate oligosaccharides within a charged group. These new methods, like HPAEC, are capable of separating the oligosaccharides into charged groups and then separating oligosaccharides based upon size/monosaccharide composition and/or linkages within charge groups. Siemiatkoski et al. also report an excellent separation of the neutral oligosaccharides on monoclonal antibodies using one of these columns without any organics in the mobile phases [113].

These separations on amide/amino columns are performed with fluorescently labeled oligosaccharides. The two most commonly used fluorescent labels are 2-AA (2- aminobenzoic acid) and 2-AB (2-aminobenzamide) [114], which are attached to the reducing end of the oligosaccharide using reductive amination. There is an alternative protocol for labeling with Fmoc-Cl (9-fluorenylmethyl chloroformate) where the label is attached to the reducing end of an intermediate of the oligosaccharide formed during release of the oligosaccharide by PNG'ase F [115]. The different types of labeling used for carbohydrates are reviewed in $[114,116]$.

RP-HPLC is another separation that has been used for oligosaccharide profiling [112, 117]. And more recently RP-HPLC using graphitized carbon columns [118] because they retain carbohydrates better (even underivitized) than other reversed-phase resins. Both these separations have the disadvantage of not being able to separate into charged groups. Since negatively-charged groups (sialic acid, phosphate and sulfate) are often critical to the function of glycoproteins it is preferable to be able to easily determine changes in the amount of charged oligosaccharides on your molecule, which is easier done with separations involving anion-exchange. However, RP-HPLC has been shown to work very well in LC-MS applications [119].

The methods used for profiling O-glycans are very similar to those used for $\mathrm{N}$-glycans except there is no enzyme commercially available that will release all $\mathrm{O}$ glycans from proteins. O-Glycanase will release certain Oglycans, but not all, from proteins [120]. O-glycans must therefore be released chemically from proteins and as a consequence of the chemical release care must be taken to not degrade the released oligsaccharide in the process. The most common technique is $\beta$-elimination [121]. This $\beta$ elimination has the disadvantage of producing reduced oligosaccharides, which precludes using reductive amination to label the released oligosaccharides with a chromophore/fluorophore (the most common method for labeling oligosaccharides).

There are several methods that leave the reducing end of the O-glycan intact. The most common method is hydrazinolysis. Hydrazinolysis is also used to release $\mathrm{N}$-glycans but by altering the temperature of the reaction it is possible to favour the release of $\mathrm{N}$-linked or O-linked oligosaccharides [96, 97]. The disadvantages for releasing O-glycans are the same as described for the removal of $\mathrm{N}$-linked oligosaccharides (see above). However, using this release method has allowed for fluorescent labeling of the released O-links and separation by normal-phase chromatography $[122,123]$.

A method using ethylamine to remove O-glycans has been reported [124] although with a low recovery of Oglycans relative to the original $\beta$-elimination. An ammonium based $\beta$-elimination [125] has recently become popular (and is in use in our labs). This method releases both Nlinked and O-linked oligosaccharides. Both of these 
methods release glycans with the reducing end intact allowing for labeling of the released oligosaccharides.

Due to the greater difficulty in removing O-links from the protein, especially without losing the reducing end, there are far fewer examples of oligosaccharide profiles of O-glycans. HPAEC-PAD has been used [126] and the separation of neutral O-links on an amino column [127, 128]. There are also reports of separation on amide columns [111, 129] and also RP-HPLC separations [123, 128].

As with $\mathrm{N}$-linked oligosaccharide profiling, it is also possible to perform LC-MS using some of these profiling methods [128, 130, 131].

When more specific details of the glycosylation of your molecule is necessary an oligosaccharide profile alone will not provide sufficient information on the oligosaccharides present. A more extensive characterization might be necessary in order to select an expression system, cell culture conditions or optimize purification of the molecule. Certain lots of material also require a more detailed analysis of the glycosylation (i.e. reference lots, validation or process qualification lots and comparability studies). Adding additional testing of key lots and demonstrating that these lots are comparable, as shown by the oligosaccharide profiling method, serves to validate that the oligosaccharide profiling method(s) is sufficient for demonstrating consistent glycosylation and that the method is not missing any changes in glycosylation. The methods used for identification of the oligosaccharides are described later in this review (under Structural Characterization), but some of the HPLC methods have the advantage of working as LC-MS methods [132] and CE can also be coupled to MS (reviewed in [133, 134]).

Due to the complexity of oligosaccharides, information from two or more techniques may be required to confirm the identity of certain oligosaccharides. For instance, the retention time of an oligosaccharide on an oligosaccharide profile or the mass could be consistent with a fucosylated oligosaccharide structure and monocompositional analysis could support the presence of fucose on the glycoprotein (or on the isolated oligosaccharide itself). Further information from techniques such as oligosaccharide sequencing using fucosidases, GC-MS analysis or MS ${ }^{\mathrm{n}}$ would still be required to determine the position and linkage of the fucose residue.

\section{Monosaccharide composition}

For the determination of the monosaccharide composition of glycoproteins or glycans, oligosaccharides are hydrolyzed into monosaccharides and the monosaccharides are then separated and quantified. Typically, fucose, galactose, mannose, GlcNAc and GalNAc are measured since they are the most common monosaccharides; however, there are methods that can be used to separate different mixes of monosaccharides. This discussion will focus on methods used to measure the monosaccharides present on a glycoprotein; similar methods can also be optimized for isolated oligosaccharides or polysaccharides. The downside of monosaccharide analysis is that much information is lost upon hydrolysis (size of oligosaccharides, branching) and therefore, it is always more informative to examine the intact oligosaccharides rather than measuring the hydrolyzed monosaccharides.

Two methods have been most commonly used for monosaccharide analysis: gas-liquid chromatography coupled with mass spectrometry and HPLC. Due to the chemistry involved in the GC methods and the more specialized equipment required for this analysis, the HPLC methods are much more commonly used. More information on the GC methods can be found in the following references [135-138] but this review will concentrate on the HPLC and CE methods.

All of the HPLC and CE methods require that oligosaccharides are first hydrolyzed into their consistuent monosaccharide units using acid hydrolysis. Choosing conditions for the acid hydrolysis is complicated because no acid hydrolysis has been demonstrated to work for all glycans. Different monosaccharides are released at different rates by and the rate of release can even be affected by their glycosidic linkage. Once released, monosaccharides are destroyed at different rates by the acid. In particular, GlcNAc and GalNAc residues are much more stable in acid and more difficult to hydrolyze than the other monosaccharides ([139] and reviewed in [140]).

For the best accuracy, the recommendation has been to hydrolyze at $100^{\circ} \mathrm{C}$ in $4 \mathrm{M} \mathrm{HCl}$ for $6 \mathrm{~h}$ for amino sugars and $2 \mathrm{M}$ TFA for $4 \mathrm{~h}$ for the other neutral monosaccharides $[84,139]$. In practice, most laboratories settle for a compromise of $2 \mathrm{M}$ TFA for $3-6 \mathrm{~h}$ at $100^{\circ} \mathrm{C}[84,139$, 141] understanding that the amino sugars will not be $100 \%$ released from the sample, but finding that two separate hydrolyses are not worth the effort given the limitations of this analysis. An alternative method using $4 \mathrm{~N}$ TFA for $2 \mathrm{~h}$ at $121^{\circ} \mathrm{C}$ for all monosaccharides has also been reported [142].

Once the hydrolysis of the monosaccharides is complete then the monosaccharides can be separated underivatized by HPAEC and detected by PAD or they can be labeled and separated by HPLC or CE (reviewed by Anumula [114]).

\section{Sialic acid analysis}

Sialic acids are a family of negatively charged monosaccharides (reviewed in [143]) that are usually found at the termini of oligosaccharides. Typically, the addition of sialic acid to oligosaccharide chains prohibits any further elon- 
gation of the oligosaccharide chains, although in some cells sialic acid polymers (with sialic acids linked $\alpha 2-8$ to each other) are formed [144]. The most common sialic acid is $N$ actetylneuraminic acid (abbreviated as NeuAc, Neu5Ac or NANA) but there are many possible modifications of this molecule. The modification that is found on many therapeutic glycoproteins and has received much attention is $\mathrm{N}$-glycolylneuraminic acid (abbreviated as NeuGc, Neu5Gc or NGNA). As discussed earlier in this review humans are unable to synthesize NeuGc.

Sialic acids are easier to remove from oligosaccharide chains, but they are also more acid labile. They are hydrolyzed using milder hydrolysis conditions than other monosaccharides. With the milder acid hydrolysis there is much less destruction of the released sialic acid than seen during the hydrolysis of neutral monosaccharides where there is significant destruction of the released monosaccharides. Quantitative release of sialic acids is also much easier to achieve than for some of the neutral monosaccharides that are difficult to hydrolyze. The most common methods for sialic acid analysis are reviewed in Manzi [145] and Zanetta [146].

\section{Specialized methods}

Oligosaccharides on some therapeutics will have a modification that will require development of a specialized assay. Two examples are: galactose residues linked $\alpha 1-3$ to galactose residues and mannose 6-phosphate residues. $\mathrm{Gal} \alpha \mathrm{Gal}$ is of interest because some expression systems will add these structures and humans do not add galactose in this linkage [147]. As well, all humans have high concentrations of antibodies against this epitope in their serum [147]. Mannose 6-phosphate is added to lysosomal proteins to assist in targeting to the lysosome $[148,149]$ but can also be found on other proteins (Deoxyribonuclease I, for example [23]). This residue may impact the clearance of molecules because there are receptors involved in the clearance of glycoproteins from the bloodstream that recognize mannose 6-phosphate residues (reviewed in [150]). There is also the possibility of monosaccharides that may, or may not, be measured in the monosaccharide analysis. An example of this would be monosaccharides commonly found in plants [151].

\section{Site-specific analysis}

Different glycosylation sites on the same glycoprotein can carry different types of oligosaccharides and differences in the occupancy of certain glycosylation sites can affect the efficacy of a molecule (t-PA is an example and this is reviewed in [152]). Consequently, there are times when the oligosaccharides at specific glycosylation sites need to be characterized. This is usually accomplished by LC-MS analysis of peptide maps where the glycosylation sites can often be isolated on different peptides [100, 153].

\section{Identification of oligosaccharide structures/structural analysis/sequencing}

Sometimes it is necessary to characterize the oligosaccharide structures present on the glycoprotein. This characterization can range from simply determining whether the oligosaccharides are oligomannose/complex and the relative size (the number of mannose residues or antennarity) to determining the glycosidic linkage of each monosaccharide on the oligosaccharide. We now understand that glycosidic linkages are carefully controlled by the glycosyltransferases that synthesize oligosaccharides and there is a great deal of information on the types of oligosaccharides found in the commonly used expression systems. It is therefore usually not necessary to determine the glycosidic linkages of the oligosaccharides, especially since they rarely have an impact on the efficacy of glycoproteins.

This information was historically obtained by GC-MS (gas chromatography mass spectrometry) or NMR (nuclear magnetic resonance) [123, 153, 154]. Oligosaccharides are now mostly sequenced by digesting with exoglycosidases or by mass spectrometry with fragmentation. Exoglycosidases are enzymes that release monosaccharides from an oligosaccharide and some will only release a specific monosaccharide or even a specific monosaccharide in one type of glycosidic linkage. The removal of monosaccharides can be monitored by shifts in the retention time of the oligosaccharide after digestion [155] or by changes in the mass by mass spectrometry [156-159]. Unfortunately, glycosidase sequencing is complicated, because it is possible to find commercial sources of neither all the exoglycosidases necessary to completely sequence an oligosaccharide structure nor the oligosaccharide standards necessary to identify an oligosaccharide. Oligosaccharide standards are necessary to help interpret shifts in oligosaccharides after digestion with glycosidases.

\section{Conclusions}

Much was learned from the extensive characterization of the early glycoprotein therapeutics and as more and more therapeutics are developed we have added to this body of knowledge. Data has been accumulated on the glycosylation added to many different proteins by the most common expression systems $[4,160]$. This information is very useful 
in predicting how a molecule will be glycosylated by a particular expression system, for choosing the best expression system for your molecule and for anticipating problems that may arise because of the chosen expression system.

Over time, oligosaccharide profiling has replaced monosaccharide composition analysis as the method of choice for characterizing therapeutic glycoproteins and especially for release testing and comparability/consistency testing. However, most therapeutic glycoproteins will require more exhaustive testing at times during their development and possibly for product release as well. The most recent advances in carbohydrate analysis have been the use of fluorescent probes for HPLC analysis and the much more common use of mass spectrometry, particularly MALDITOF MS. Hopefully, in the near future, LC-MS (and LCMS-MS) methods for oligosaccharide analysis will become more widely available making it easier to unequivocally identify oligosaccharide structures.

Acknowledgements The author wishes to thank Amy Lachapelle and Liz Kast for the critical review of this manuscript.

Open Access This article is distributed under the terms of the Creative Commons Attribution Noncommercial License which permits any noncommercial use, distribution, and reproduction in any medium, provided the original author(s) and source are credited.

\section{References}

1. Raju, T.S.: Glycosylation Variations with Expression Systems and Their Impact on Biological Activity of Therapeutic Immunoglobulins. Bioprocess Int 2003, 44-54 (2003)

2. Betenbaugh, M.J., Tomiya, N., Narang, S., Hsu, J.T., Lee, Y.C.: Biosynthesis of human-type N-glycans in heterologous systems. Curr Opin Struct Biol 14, 601-606 (2004)

3. Lipscomb, M.L., Palomares, L.A., Hernandez, V., Ramirez, O.T., Kompala, D.S.: Effect of production method and gene amplification on the glycosylation pattern of a secreted reporter protein in CHO cells. Biotechnol Prog 21, 40-49 (2005)

4. Grabenhorst, E., Schlenke, P., Pohl, S., Nimtz, M., Conradt, H.S.: Genetic engineering of recombinant glycoproteins and the glycosylation pathway in mammalian host cells. Glycoconj J 16, 81-97 (1999)

5. Lee, K., Jin, X., Zhang, K., Copertino, L., Andrews, L., BakerMalcolm, J., Geagan, L., Qiu, H., Seiger, K., Barngrover, D., McPherson, J.M., Edmunds, T.: A biochemical and pharmacological comparison of enzyme replacement therapies for the glycolipid storage disorder Fabry disease. Glycobiology 13, 305-313 (2003). Epub 2003 Jan 2003

6. Matsuura, F., Ohta, M., Ioannou, Y., Desnick, R.: Human $\alpha$ galactosidase A: characterization of the $\mathrm{N}$-linked oligosaccharides on the intracellular and secreted glycoforms overexpressed by Chinese hamster ovary cells. Glycobiology. 8, 329-339 (1998)

7. Meier, W., Gill, A., Rogge, M., Dabora, R., Majeau, G.R., Oleson, F.B., Jones, W.E., Frazier, D., Miatkowski, K., Hochman, P.S.: Immunomodulation by LFA3TIP, an LFA-3/IgG1 fusion protein: cell line dependent glycosylation effects on pharmacokinetics and pharmacodynamic markers. Ther Immunol 2, 159-171 (1995)
8. Mutsaers, J.H., Van Halbeek, H., Vliegenthart, J.F., Tager, J.M., Reuser, A.J., Kroos, M., Galjaard, H.: Determination of the structure of the carbohydrate chains of acid alpha-glucosidase from human placenta. Biochim Biophys Acta 911, 244-251 (1987)

9. Jongen, S.P., Gerwig, G.J., Leeflang, B.R., Koles, K., Mannesse, M.L., van Berkel, P.H., Pieper, F.R., Kroos, M.A., Reuser, A.J., Zhou, Q., Jin, X., Zhang, K., Edmunds, T., Kamerling, J.P.: Nglycans of recombinant human acid $\alpha$-glucosidase expressed in the milk of transgenic rabbits. Glycobiology 17, 600-619 (2007). Epub 2007 Feb 2009

10. Pohl, G., Kallstrom, M., Bergsdorf, N., Wallen, P., Jornvall, H.: Tissue plasminogen activator: peptide analyses confirm an indirectly derived amino acid sequence, identify the active site serine residue, establish glycosylation sites, and localize variant differences. Biochemistry 23, 3701-3707 (1984)

11. Parekh, R.B., Dwek, R.A., Rudd, P.M., Thomas, J.R., Rademacher, T.W., Warren, T., Wun, T.C., Hebert, B., Reitz, B., Palmier, M., Opdenakker, G., Wittwer, A.J., Howard, S.C., Nelson, R., Siegel, N.R., Jennings, M.G., Spellman, M.W., Basa, L.J., Leonard, C.K., Chakel, J.A., O'Connor, J.V., Wilson, S., van Halbeek, H., et al.: N-glycosylation and in vitro enzymatic activity of human recombinant tissue plasminogen activator expressed in Chinese hamster ovary cells and a murine cell line. Biochemistry 28, 7670-7679 (1989)

12. Parekh, R.B., Dwek, R.A., Thomas, J.R., Opdenakker, G., Rademacher, T.W., Wittwer, A.J., Howard, S.C., Nelson, R., Siegel, N.R., Jennings, M.G., Spellman, M.W., Basa, L.J., Leonard, C.K., Chakel, J.A., O'Connor, J.V., Wilson, S., van Halbeek, H., et al.: Cell-type-specific and site-specific Nglycosylation of type I and type II human tissue plasminogen activator. Biochemistry 28, 7644-7662 (1989)

13. Spellman, M.W., Basa, L.J., Leonard, C.K., Chakel, J.A., O'Connor, J.V., Wilson, S., van Halbeek, H.: Carbohydrate structures of human tissue plasminogen activator expressed in Chinese hamster ovary cells. J Biol Chem 264, 14100-14111 (1989)

14. Hironaka, T., Furukawa, K., Esmon, P.C., Fournel, M.A., Sawada, S., Kato, M., Minaga, T., Kobata, A.: Comparative study of the sugar chains of factor VIII purified from human plasma and from the culture media of recombinant baby hamster kidney cells. J Biol Chem 267, 8012-8020 (1992)

15. Kumar, H.P., Hague, C., Haley, T., Starr, C.M., Besman, M.J., Lundblad, R.L., Baker, D.: Elucidation of N-linked oligosaccharide structures of recombinant human factor VIII using fluorophore-assisted carbohydrate electrophoresis. Biotechnol Appl Biochem 24, 207-216 (1996)

16. Edmunds, T., Van Patten, S.M., Pollock, J., Hanson, E., Bernasconi, R., Higgins, E., Manavalan, P., Ziomek, C., Meade, H., McPherson, J.M., Cole, E.S.: Transgenically produced human antithrombin: structural and functional comparison to human plasma-derived antithrombin. Blood 91, 4561-4571 (1998)

17. Zhou, Q., Kyazike, J., Echelard, Y., Meade, H.M., Higgins, E., Cole, E.S., Edmunds, T.: Effect of genetic background on glycosylation heterogeneity in human antithrombin produced in the mammary gland of transgenic goats. J Biotechnol 117, 57-72 (2005)

18. Kessler, M.J., Mise, T., Ghai, R.D., Bahl, O.P.: Structure and location of the O-glycosidic carbohydrate units of human chorionic gonadotropin. J Biol Chem 254, 7909-7914 (1979)

19. Weisshaar, G., Hiyama, J., Renwick, A.G.: Site-specific Nglycosylation of human chorionic gonadotrophin-structural analysis of glycopeptides by one- and two-dimensional $1 \mathrm{H}$ NMR spectroscopy. Glycobiology 1, 393-404 (1991)

20. Liu, C., Bowers, L.D.: Mass spectrometric characterization of the beta-subunit of human chorionic gonadotropin. J Mass Spectrom 32, 33-42 (1997) 
21. Takeuchi, M., Kobata, A.: Structures and functional roles of the sugar chains of human erythropoietins. Glycobiology 1, 337-346 (1991)

22. Lai, P., Everett, R., Wang, F., Arakawa, T., Goldwasser, E.: Structural characterization of human erythropoietin. J Biol Chem 261, 3116-3121 (1986)

23. Cacia, J., Quan, C.P., Pai, R., Frenz, J.: Human DNase I contains mannose 6-phosphate and binds the cation-independent mannose 6-phosphate receptor. Biochemistry 37, 15154-15161 (1998)

24. Yan, S.B., Chao, Y.B., van Halbeek, H.: Novel Asn-linked oligosaccharides terminating in GalNAc beta $(1 \rightarrow 4)$ [Fuc alpha $(1 \rightarrow 3)]$ GlcNAc beta $(1 \rightarrow$.) are present in recombinant human protein C expressed in human kidney 293 cells. Glycobiology 3, 597-608 (1993)

25. Hokke, C.H., Bergwerff, A.A., Van Dedem, G.W., Kamerling, J. P., Vliegenthart, J.F.: Structural analysis of the sialylated N- and O-linked carbohydrate chains of recombinant human erythropoietin expressed in Chinese hamster ovary cells. Sialylation patterns and branch location of dimeric $\mathrm{N}$-acetyllactosamine units. Eur J Biochem 228, 981-1008 (1995)

26. Pennica, D., Lam, V.T., Weber, R.F., Kohr, W.J., Basa, L.J., Spellman, M.W., Ashkenazi, A., Shire, S.J., Goeddel, D.V.: Biochemical characterization of the extracellular domain of the 75-kilodalton tumor necrosis factor receptor. Biochemistry 32, 3131-3138 (1993)

27. Jurlander, B., Thim, L., Klausen, N.K., Persson, E., Kjalke, M., Rexen, P., Jorgensen, T.B., Ostergaard, P.B., Erhardtsen, E., Bjorn, S.E.: Recombinant activated factor VII (rFVIIa): characterization, manufacturing, and clinical development. Semin Thromb Hemost 27, 373-384 (2001)

28. Kaufman, R., Wasley, L., Dorner, A.: Synthesis, processing, and secretion of recombinant human factor VIII expressed in mammalian cells. J Biol Chem. 263, 6352-6362 (1988)

29. Fischer, B., Mitterer, A., Dorner, F., Eibl, J.: Comparison of NGlycan Pattern of Recombinant Human Coagulation Factors II and IX Expressed in Chinese Hamster Ovary (CHO) and African Green Monkey (Vero) Cells. J Thromb Thrombolysis 3, 57-62 (1996)

30. Agarwala, K.L., Kawabata, S., Takao, T., Murata, H., Shimonishi, Y., Nishimura, H., Iwanaga, S.: Activation peptide of human factor IX has oligosaccharides O-glycosidically linked to threonine residues at 159 and 169. Biochemistry 33, 5167-5171 (1994)

31. Harris, R.J., van Halbeek, H., Glushka, J., Basa, L.J., Ling, V.T., Smith, K.J., Spellman, M.W.: Identification and structural analysis of the tetrasaccharide NeuAc alpha $(2 \rightarrow 6)$ Gal $\beta(\rightarrow 4)$ GlcNAc $\beta(1 \rightarrow 3)$ Fuc $\alpha 1 \rightarrow$ O-linked to serine 61 of human factor IX. Biochemistry 32, 6539-6547 (1993)

32. de Leeuw, R., Mulders, J., Voortman, G., Rombout, F., Damm, J., Kloosterboer, L.: Structure-function relationship of recombinant follicle stimulating hormone (Puregon). Mol Hum Reprod 2, 361-369 (1996)

33. Hard, K., Mekking, A., Damm, J.B., Kamerling, J.P., de Boer, W., Wijnands, R.A., Vliegenthart, J.F.: Isolation and structure determination of the intact sialylated N-linked carbohydrate chains of recombinant human follitropin expressed in Chinese hamster ovary cells. Eur J Biochem 193, 263-271 (1990)

34. Peters, C., Schmidt, B., Rommerskirch, W., Rupp, K., Zuhlsdorf, M., Vingron, M., Meyer, H.E., Pohlmann, R., von Figura, K.: Phylogenetic conservation of arylsulfatases. cDNA cloning and expression of human arylsulfatase. B J Biol Chem 265, 33743381 (1990)

35. Petre, J., Rutgers, T., Hauser, P.: Properties of a recombinant yeast-derived hepatitis B surface antigen containing S, preS2 and preS1 antigenic domains. Arch Virol Suppl 4, 137-141 (1992)

36. Heermann, K.H., Goldmann, U., Schwartz, W., Seyffarth, T., Baumgarten, H., Gerlich, W.H.: Large surface proteins of hepatitis B virus containing the pre-s sequence. J Virol. 52, 396-402 (1984)

37. Schmitt, S., Glebe, D., Tolle, T.K., Lochnit, G., Linder, D., Geyer, R., Gerlich, W.H.: Structure of pre-S2 N- and O-linked glycans in surface proteins from different genotypes of hepatitis B virus. J Gen Virol 85, 2045-2053 (2004)

38. Zhou, J., Sun, X.Y., Frazer, I.H.: Glycosylation of human papillomavirus type 16 L1 protein. Virology 194, 210-218 (1993)

39. Fiszer-Szafarz, B., Litynska, A., Zou, L.: Human hyaluronidases: electrophoretic multiple forms in somatic tissues and body fluids. Evidence for conserved hyaluronidase potential N-glycosylation sites in different mammalian species. J Biochem Biophys Methods 45, 103-116 (2000)

40. Takasaki, S., Murray, G.J., Furbish, F.S., Brady, R.O., Barranger, J.A., Kobata, A.: Structure of the N-asparagine-linked oligosaccharide units of human placental $\beta$-glucocerebrosidase. J Biol Chem 259, 10112-10117 (1984)

41. Furbish, F.S., Steer, C.J., Krett, N.L., Barranger, J.A.: Uptake and distribution of placental glucocerebrosidase in rat hepatic cells and effects of sequential deglycosylation. Biochim Biophys Acta 673, 425-434 (1981)

42. Edmunds, T.: Cerezyme: a case study. Dev Biol Stand 96, 131140 (1998)

43. Taniguchi, T., Ohno, S., Fujii-Kuriyama, Y., Muramatsu, M.: The nucleotide sequence of human fibroblast interferon cDNA. Gene 10, 11-15 (1980)

44. Karpusas, M., Nolte, M., Benton, C.B., Meier, W., Lipscomb, W. N., Goelz, S.: The crystal structure of human interferon $\beta$ at 2.2A resolution. Proc Natl Acad Sci U S A 94, 11813-11818 (1997)

45. Conradt, H.S., Egge, H., Peter-Katalinic, J., Reiser, W., Siklosi, T., Schaper, K.: Structure of the carbohydrate moiety of human interferon- $\beta$ secreted by a recombinant Chinese hamster ovary cell line. J Biol Chem 262, 14600-14605 (1987)

46. Kagawa, Y., Takasaki, S., Utsumi, J., Hosoi, K., Shimizu, H., Kochibe, N., Kobata, A.: Comparative study of the asparaginelinked sugar chains of natural human interferon- $\beta 1$ and recombinant human interferon- $\beta 1$ produced by three different mammalian cells. J Biol Chem 263, 17508-17515 (1988)

47. Hague, C., Masada, R.I., Starr, C.: Structural determination of oligosaccharides from recombinant iduronidase released with peptide $\mathrm{N}$-glycanase $\mathrm{F}$ using fluorophore-assisted carbohydrate electrophoresis. Electrophoresis 19, 2612-2620 (1998)

48. Zhao, K.W., Faull, K.F., Kakkis, E.D., Neufeld, E.F.: Carbohydrate structures of recombinant human $\alpha$-L-iduronidase secreted by Chinese hamster ovary cells. J Biol Chem 272, 22758-22765 (1997)

49. Kubota, N., Orita, T., Hattori, K., Oh-eda, M., Ochi, N., Yamazaki, T.: Structural characterization of natural and recombinant human granulocyte colony-stimulating factors. J Biochem (Tokyo) 107, 486-492 (1990)

50. Green, E.D., Baenziger, J.U.: Asparagine-linked oligosaccharides on lutropin, follitropin, and thyrotropin. II. Distributions of sulfated and sialylated oligosaccharides on bovine, ovine, and human pituitary glycoprotein hormones. J Biol Chem 263, 36-44 (1988)

51. Green, E.D., Baenziger, J.U.: Asparagine-linked oligosaccharides on lutropin, follitropin, and thyrotropin. I. Structural elucidation of the sulfated and sialylated oligosaccharides on bovine, ovine, and human pituitary glycoprotein hormones. J Biol Chem 263, 25-35 (1988)

52. Jones, W.K., Richmond, E.A., White, K., Sasak, H., Kusmik, W., Smart, J., Oppermann, H., Rueger, D.C., Tucker, R.F.: Osteogenic protein-1 (OP-1) expression and processing in Chinese hamster ovary cells: isolation of a soluble complex containing the mature and pro-domains of OP-1. Growth Factors 11, 215225 (1994) 
53. Zhou, Q., Park, S.H., Boucher, S., Higgins, E., Lee, K., Edmunds, T.: $\mathrm{N}$-linked oligosaccharide analysis of glycoprotein bands from isoelectric focusing gels. Anal Biochem 335, 10-16 (2004)

54. Cole, E.S., Lee, K., Lauziere, K., Kelton, C., Chappel, S., Weintraub, B., Ferrara, D., Peterson, P., Bernasconi, R., Edmunds, T., et al:: Recombinant human thyroid stimulating hormone: development of a biotechnology product for detection of metastatic lesions of thyroid carcinoma. Biotechnology (N Y) 11, 1014-1024 (1993)

55. Spellman, M.W.: Carbohydrate characterization of recombinant glycoproteins of pharmaceutical interest. Anal Chem 62, 1714 $1722(1990)$

56. Vliegenthart, J.F., Casset, F.: Novel forms of protein glycosylation. Curr Opin Struct Biol 8, 565-571 (1998)

57. Spiro, R.G.: Protein glycosylation: nature, distribution, enzymatic formation, and disease implications of glycopeptide bonds. Glycobiology 12, 43R-56R (2002)

58. Jefferis, R.: Antibody therapeutics: isotype and glycoform selection. Expert Opin Biol Ther 7, 1401-1413 (2007)

59. Werner, R.G., Kopp, K., Schlueter, M.: Glycosylation of therapeutic proteins in different production systems. Acta Paediatr Suppl 96, 17-22 (2007)

60. Einarsson, M., Brandt, J., Kaplan, L.: Large-scale purification of human tissue-type plasminogen activator using monoclonal antibodies. Biochim Biophys Acta 830, 1-10 (1985)

61. Opdenakker, G., Van Damme, J., Bosman, F., Billiau, A., De Somer, P.: Influence of carbohydrate side chains on activity of tissue-type plasminogen activator. Proc Soc Exp Biol Med 182, 248-257 (1986)

62. Wittwer, A.J., Howard, S.C., Carr, L.S., Harakas, N.K., Feder, J., Parekh, R.B., Rudd, P.M., Dwek, R.A., Rademacher, T.W.: Effects of N-glycosylation on in vitro activity of Bowes melanoma and human colon fibroblast derived tissue plasminogen activator. Biochemistry 28, 7662-7669 (1989)

63. Smedsrod, B., Einarsson, M., Pertoft, H.: Tissue plasminogen activator is endocytosed by mannose and galactose receptors of rat liver cells. Thromb Haemost 59, 480-484 (1988)

64. Hotchkiss, A., Refino, C.J., Leonard, C.K., O'Connor, J.V., Crowley, C., McCabe, J., Tate, K., Nakamura, G., Powers, D., Levinson, A., et al.: The influence of carbohydrate structure on the clearance of recombinant tissue-type plasminogen activator. Thromb Haemost 60, 255-261 (1988)

65. Collen, D., Stassen, J.M., Larsen, G.: Pharmacokinetics and thrombolytic properties of deletion mutants of human tissue-type plasminogen activator in rabbits. Blood 71, 216-219 (1988)

66. Rambach, W.A., Shaw, R.A., Cooper, J.A., Alt, H.L.: Acid hydrolysis of erythropoietin. Proc Soc Exp Biol Med 99, 482483 (1958)

67. Lukowsky, W.A., Painter, R.H.: Studies on the role of sialic acid in the physical and biological properties of erythropoietin. Can J Biochem 50, 909-917 (1972)

68. Goldwasser, E., Kung, C.K., Eliason, J.: On the mechanism of erythropoietin-induced differentiation. 13. The role of sialic acid in erythropoietin action. J Biol Chem 249, 4202-4206 (1974)

69. Bu, G., Williams, S., Strickland, D.K., Schwartz, A.L.: Low density lipoprotein receptor-related protein $/ \alpha$ 2-macroglobulin receptor is an hepatic receptor for tissue-type plasminogen activator. Proc Natl Acad Sci U S A 89, 7427-7431 (1992)

70. Orth, K., Willnow, T., Herz, J., Gething, M.J., Sambrook, J.: Low density lipoprotein receptor-related protein is necessary for the internalization of both tissue-type plasminogen activatorinhibitor complexes and free tissue-type plasminogen activator. J Biol Chem 269, 21117-21122 (1994)

71. Kuiper, J., Otter, M., Rijken, D., van Berkel, T.: Characterization of the interaction in vivo of tissue-type plasminogen activator with liver cells. J Biol Chem 263, 18220-18224 (1988)
72. Smedsrod, B., Einarsson, M.: Clearance of tissue plasminogen activator by mannose and galactose receptors in the liver. Thromb Haemost 63, 60-66 (1990)

73. Noorman, F., Barrett-Bergshoeff, M.M., Rijken, D.C.: Role of carbohydrate and protein in the binding of tissue-type plasminogen activator to the human mannose receptor. Eur J Biochem 251, 107-113 (1998)

74. Larsen, G., Metzger, M., Henson, K., Blue, Y., Horgan, P.: Pharmacokinetic and distribution analysis of variant forms of tissue- type plasminogen activator with prolonged clearance in rat. Blood 73, 1842-1850 (1989)

75. Kuiper, J., van de Bilt, H., Martin, U., van Berkel, T.J.: Uptake, internalization and degradation of the novel plasminogen activator reteplase (BM 06.022) in the rat. Thromb Haemost 74, 1501-1510 (1995)

76. Sasaki, H., Bothner, B., Dell, A., Fukuda, M.: Carbohydrate Structure of Erythropoietin Expressed in Chinese Hamster Ovary Cells by a Human Erythropoietin cDNA. J Biol Chem 262, 12059-12076 (1987)

77. Dube, S., Fisher, J.W., Powell, J.S.: Glycosylation at specific sites of erythropoietin is essential for biosynthesis, secretion, and biological function. J Biol Chem 263, 17516-17521 (1988)

78. Jenkins, N., Curling, E.M.: Glycosylation of recombinant proteins: problems and prospects. Enzyme Microb Technol 16, 354-364 (1994)

79. Dordal, M.S., Wang, F.F., Goldwasser, E.: The role of carbohydrate in erythropoietin action. Endocrinology 116, 2293-2299 (1985)

80. Takeuchi, M., Takasaki, S., Shimada, M., Kobata, A.: Role of sugar chains in the in vitro biological activity of human erythropoietin produced in recombinant Chinese hamster ovary cells. J Biol Chem 265, 12127-12130 (1990)

81. Ashwell, G., Harford, J.: Carbohydrate-specific receptors of the liver. Annu Rev Biochem 51, 531-554 (1982)

82. Takeuchi, M., Inoue, N., Strickland, T.W., Kubota, M., Wada, M., Shimizu, R., Hoshi, S., Kozutsumi, H., Takasaki, S., Kobata, A.: Relationship between sugar chain structure and biological activity of recombinant human erythropoietin produced in Chinese hamster ovary cells. Proc Natl Acad Sci U S A 86, 7819-7822 (1989)

83. Macdougall, I.C.: Optimizing the use of erythropoietic agents pharmacokinetic and pharmacodynamic considerations. Nephrol Dial Transplant 17(Suppl 5), 66-70 (2002)

84. Hardy, M.R., Townsend, R.R., Lee, Y.C.: Monosaccharide analysis of glycoconjugates by anion exchange chromatography with pulsed amperometric detection. Anal Biochem 170, 54-62 (1988)

85. Chen, L.M., Yet, M.G., Shao, M.C.: New methods for rapid separation and detection of oligosaccharides from glycoproteins. Faseb J 2, 2819-2824 (1988)

86. Townsend, R.R., Hardy, M.R.: Analysis of glycoprotein oligosaccharides using high-pH anion exchange chromatography. Glycobiology 1, 139-147 (1991)

87. Lee, Y.C.: High-performance anion-exchange chromatography for carbohydrate analysis. Anal Biochem 189, 151-162 (1990)

88. Tangvoranuntakul, P., Gagneux, P., Diaz, S., Bardor, M., Varki, N., Varki, A., Muchmore, E.: Human uptake and incorporation of an immunogenic nonhuman dietary sialic acid. Proc Natl Acad Sci U S A 100, 12045-12050 (2003). Epub 12003 Oct 12041

89. Hedlund, M., Tangvoranuntakul, P., Takematsu, H., Long, J.M., Housley, G.D., Kozutsumi, Y., Suzuki, A., Wynshaw-Boris, A., Ryan, A.F., Gallo, R.L., Varki, N., Varki, A.: Nglycolylneuraminic acid deficiency in mice: implications for human biology and evolution. Mol Cell Biol 27, 4340-4346 (2007) 
90. Byres, E., Paton, A.W., Paton, J.C., Lofling, J.C., Smith, D.F., Wilce, M.C.J., Talbot, U.M., Chong, D.C., Yu, H., Huang, S., Chen, X., Varki, N.M., Varki, A., Rossjohn, J., Beddoe, T.: Incorporation of a non-human glycan mediates human susceptibility to a bacterial toxin. Nature 456, 648-652 (2008)

91. Zhu, A., Hurst, R.: Anti-N-glycolylneuraminic acid antibodies identified in healthy human serum. Xenotransplantation 9, 376$381(2002)$

92. Altmann, F., Schweiszer, S., Weber, C.: Kinetic comparison of peptide: $\mathrm{N}$-glycosidases $\mathrm{F}$ and $\mathrm{A}$ reveals several differences in substrate specificity. Glycoconj J 12, 84-93 (1995)

93. Tarentino, A.L., Gomez, C.M., Plummer Jr., T.H.: Deglycosylation of asparagine-linked glycans by peptide: $\mathrm{N}$-glycosidase $\mathrm{F}$. Biochemistry 24, 4665-4671 (1985)

94. Tretter, V., Altmann, F., Marz, L.: Peptide-N4-(N-acetyl- $\beta$ glucosaminyl)asparagine amidase $\mathrm{F}$ cannot release glycans with fucose attached alpha $1-3$ to the asparagine-linked $\mathrm{N}$ acetylglucosamine residue. Eur J Biochem 199, 647-652 (1991)

95. O'Neill, R.A.: Enzymatic release of oligosaccharides from glycoproteins for chromatographic and electrophoretic analysis. J Chromatogr A 720, 201-215 (1996)

96. Patel, T., Bruce, J., Merry, A., Bigge, C., Wormald, M., Jaques, A., Parekh, R.: Use of hydrazine to release in intact and unreduced form both $\mathrm{N}$ - and $\mathrm{O}$-linked oligosaccharides from glycoproteins. Biochemistry 32, 679-693 (1993)

97. Takasaki, S., Mizuochi, T., Kobata, A.: Hydrazinolysis of asparagine-linked sugar chains to produce free oligosaccharides. Methods Enzymol 83, 263-268 (1982)

98. Patel, T.P., Parekh, R.B.: Release of oligosaccharides from glycoproteins by hydrazinolysis. Methods Enzymol 230, 57-66 (1994)

99. Bendiak, B., Cumming, D.A.: Hydrazinolysis-N-reacetylation of glycopeptides and glycoproteins. Model studies using 2acetamido-1-N-(L-aspart-4-oyl)-2-deoxy- $\beta$-D-glucopyranosy lamine. Carbohydr Res 144, 1-12 (1985)

100. Wada, Y., Azadi, P., Costello, C.E., Dell, A., Dwek, R.A., Geyer, H., Geyer, R., Kakehi, K., Karlsson, N.G., Kato, K., Kawasaki, N., Khoo, K.H., Kim, S., Kondo, A., Lattova, E., Mechref, Y., Miyoshi, E., Nakamura, K., Narimatsu, H., Novotny, M.V., Packer, N.H., Perreault, H., Peter-Katalinic, J., Pohlentz, G., Reinhold, V.N., Rudd, P.M., Suzuki, A., Taniguchi, N.: Comparison of the methods for profiling glycoprotein glycans-HUPO Human Disease Glycomics/Proteome Initiative multi-institutional study. Glycobiology 17, 411-422 (2007). Epub 2007 Jan 2012

101. Johannes, Stadlmann, Martin, Pabst, Daniel, Kolarich, Renate, Kunert, Friedrich, Altmann: Analysis of immunoglobulin glycosylation by LC-ESI-MS of glycopeptides and oligosaccharides. PROTEOMICS 8, 2858-2871 (2008)

102. Raju, T.S.: Electrophoretic methods for the analysis of N-linked oligosaccharides. Anal Biochem 283, 125-132 (2000)

103. Dell, A., Morris, H.R.: Glycoprotein structure determination by mass spectrometry. Science 291, 2351-2356 (2001)

104. Kamoda, S., Ishikawa, R., Kakehi, K.: Capillary electrophoresis with laser-induced fluorescence detection for detailed studies on $\mathrm{N}$-linked oligosaccharide profile of therapeutic recombinant monoclonal antibodies. J Chromatogr A 1133, 332-339 (2006). Epub 2006 Sep 2001

105. Kamoda, S., Kakehi, K.: Capillary electrophoresis for the analysis of glycoprotein pharmaceuticals. Electrophoresis 27, 2495-2504 (2006)

106. Mechref, Y., Novotny, M.V.: Structural investigations of glycoconjugates at high sensitivity. Chem Rev 102, 321-369 (2002)

107. Hardy, M.R., Townsend, R.R.: Separation of positional isomers of oligosaccharides and glycopeptides by high-performance anion-exchange chromatography with pulsed amperometric detection. Proc Natl Acad Sci U S A 85, 3289-3293 (1988)
108. Baenziger, J.U.: High-performance liquid chromatography of oligosaccharides. Methods Enzymol 230, 237-249 (1994)

109. Townsend, R.R., Lipniunas, P.H., Bigge, C., Ventom, A., Parekh, R.: Multimode high-performance liquid chromatography of fluorescently labeled oligosaccharides from glycoproteins. Anal Biochem 239, 200-207 (1996)

110. Anumula, Dhume: High Resolution and High Sensitivity Methods for Oligosaccharide Mapping and Characterization. Glycobiology 8, 685 (1998)

111. Guile, G.R., Rudd, P.M., Wing, D.R., Prime, S.B., Dwek, R.A.: A rapid high-resolution high-performance liquid chromatographic method for separating glycan mixtures and analyzing oligosaccharide profiles. Anal Biochem 240, 210-226 (1996)

112. Guile, G.R., Harvey, D.J., O'Donnell, N., Powell, A.K., Hunter, A.P., Zamze, S., Fernandes, D.L., Dwek, R.A., Wing, D.R.: Identification of highly fucosylated N-linked oligosaccharides from the human parotid gland. Eur J Biochem 258, 623-656 (1998)

113. Siemiatkoski, J., Lyubarskaya, Y., Houde, D., Tep, S., Mhatre, R.: A comparison of three techniques for quantitative carbohydrate analysis used in characterization of therapeutic antibodies. Carbohydr Res 341, 410-419 (2006). Epub 2005 Dec 2027

114. Anumula, K.R.: Advances in fluorescence derivatization methods for high-performance liquid chromatographic analysis of glycoprotein carbohydrates. Anal Biochem 350, 1-23 (2006)

115. Kamoda, S., Nakano, M., Ishikawa, R., Suzuki, S., Kakehi, K.: Rapid and sensitive screening of $\mathrm{N}$-glycans as 9-fluorenylmethyl derivatives by high-performance liquid chromatography: a method which can recover free oligosaccharides after analysis. J Proteome Res 4, 146-152 (2005)

116. Lamari, F.N., Kuhn, R., Karamanos, N.K.: Derivatization of carbohydrates for chromatographic, electrophoretic and mass spectrometric structure analysis. J Chromatogr B Analyt Technol Biomed Life Sci 793, 15-36 (2003)

117. Nakagawa, H., Kawamura, Y., Kato, K., Shimada, I., Arata, Y., Takahashi, N.: Identification of neutral and sialyl N-linked oligosaccharide structures from human serum glycoproteins using three kinds of high-performance liquid chromatography. Anal Biochem 226, 130-138 (1995)

118. Koizumi, K.: High-performance liquid chromatographic separation of carbohydrates on graphitized carbon columns. J Chromatogr A 720, 119-126 (1996)

119. Pabst, M., Bondili, J.S., Stadlmann, J., Mach, L., Altmann, F.: Mass + retention time $=$ structure: a strategy for the analysis of $\mathrm{N}$-glycans by carbon LC-ESI-MS and its application to fibrin N-glycans. Anal Chem 79, 5051-5057 (2007). Epub 2007 Jun 5051

120. Umemoto, J., Bhavanandan, V.P., Davidson, E.A.: Purification and properties of an endo-alpha-N-acetyl-D-galactosaminidase from Diplococcus pneumoniae. J Biol Chem 252, 8609-8614 (1977)

121. Carlson, D.M.: Structures and immunochemical properties of oligosaccharides isolated from pig submaxillary mucins. J Biol Chem 243, 616-626 (1968)

122. Merry, A.H., Neville, D.C., Royle, L., Matthews, B., Harvey, D. J., Dwek, R.A., Rudd, P.M.: Rudd: Recovery of intact 2aminobenzamide-labeled O-glycans released from glycoproteins by hydrazinolysis. Anal Biochem 304, 91-99 (2002)

123. Royle, L., Mattu, T.S., Hart, E., Langridge, J.I., Merry, A.H., Murphy, N., Harvey, D.J., Dwek, R.A., Rudd, P.M.: An analytical and structural database provides a strategy for sequencing O-glycans from microgram quantities of glycoproteins. Anal Biochem 304, 70-90 (2002)

124. Chai, W., Feizi, T., Yuen, C.-T., Lawson, A.M.: Nonreductive release of O-linked oligosaccharides from mucin glycoproteins 
for structure/function assignments as neoglycolipids: application in the detection of novel ligands for E-selectin 10.1093/glycob/ 7.6.861. Glycobiology 7, 861-872 (1997)

125. Huang, Y., Mechref, Y., Novotny, M.V.: Microscale nonreductive release of O-linked glycans for subsequent analysis through MALDI mass spectrometry and capillary electrophoresis. Anal Chem 73, 6063-6069 (2001)

126. Hokke, C.H., Damm, J.B., Penninkhof, B., Aitken, R.J., Kamerling, J.P., Vliegenthart, J.F.: Structure of the O-linked carbohydrate chains of porcine zona pellucida glycoproteins. Eur J Biochem 221, 491-512 (1994)

127. Klein, A., Carnoy, C., Lo-Guidice, J.M., Lamblin, G., Roussel, P.: Separation of mucin oligosaccharide-alditols by high performance liquid chromatography on alkylamine-bonded silica columns. Effects of structural parameters. Carbohydr Res 236, 9-16 (1992)

128. Thomsson, K.A., Karlsson, N.G., Hansson, G.C.: Liquid chromatography-electrospray mass spectrometry as a tool for the analysis of sulfated oligosaccharides from mucin glycoproteins. J Chromatogr A 854, 131-139 (1999)

129. Thomsson, K.A., Karlsson, H., Hansson, G.C.: Sequencing of sulfated oligosaccharides from mucins by liquid chromatography and electrospray ionization tandem mass spectrometry. Anal Chem 72, 4543-4549 (2000)

130. Schulz, B.L., Oxley, D., Packer, N.H., Karlsson, N.G.: Identification of two highly sialylated human tear-fluid DMBT1 isoforms: the major high-molecular-mass glycoproteins in human tears. Biochem J 366, 511-520 (2002)

131. Karlsson, N.G., Schulz, B.L., Packer, N.H.: Structural determination of neutral O-linked oligosaccharide alditols by negative ion LC-electrospray-MSn. J Am Soc Mass Spectrom 15, 659672 (2004)

132. Wuhrer, M., Deelder, A.M., Hokke, C.H.: Protein glycosylation analysis by liquid chromatography-mass spectrometry. J Chromatogr B Analyt Technol Biomed Life Sci 825, 124-133 (2005)

133. Campa, C., Coslovi, A., Flamigni, A., Rossi, M.: Overview on advances in capillary electrophoresis-mass spectrometry of carbohydrates: a tabulated review. Electrophoresis 27, 2027-2050 (2006)

134. Balaguer, E., Demelbauer, U., Pelzing, M., Sanz-Nebot, V., Barbosa, J., Neususs, C.: Glycoform characterization of erythropoietin combining glycan and intact protein analysis by capillary electrophoresis - electrospray - time-of-flight mass spectrometry. Electrophoresis 27, 2638-2650 (2006)

135. A. Fox, S.L. Morgan,J. Gilbart: Preparation of Alditol Acetates and their Analysis by Gas Chromatography (GC) and Mass Spectrometry (MS). Analysis of Carbohydrates by GLC and MS. 87-117 (1989)

136. K. Kakehi,S. Honda: Silyl ethers of Carbohydrates. Analysis of Carbohydrates by GLC and MS. 43-85 (1989)

137. V. Reinhold: Gas-liquid chromatographic analysis of constituent carbohydrates in glycoproteins. Methods in Enzymology. 244249 (1972)

138. Laine, R.A., Esselman, W.J., Sweeley, C.C.: Gas-liquid chromatography of carbohydrates. Methods Enzymol 28, 159-167 (1972)

139. Fan, J.Q., Namiki, Y., Matsuoka, K., Lee, Y.C.: Comparison of acid hydrolytic conditions for Asn-linked oligosaccharides. Anal Biochem 219, 375-378 (1994)

140. Marshall, R.D., Neuberger, A.: Qualitative and Quantitative Analysis of the Component Sugars. Glycoproteins Part B, 224 299 (1972)

141. R.R. Townsend, A. Manzi, R.K. Merkle, M.F. Rhode, M. Spellman, A. Smith,S.A. Carr: Quantitative Monosaccharide Analysis: A Multi-Center Study. ABRF News. March, 14-21 (1997)
142. Fu, D., O'Neill, R.A.: Monosaccharide composition analysis of oligosaccharides and glycoproteins by high-performance liquid chromatography. Anal Biochem 227, 377-384 (1995)

143. Varki, A.: Diversity in the sialic acids. Glycobiology 2, 25-40 (1992)

144. Muhlenhoff, M., Eckhardt, M., Gerardy-Schahn, R.: Polysialic acid: three-dimensional structure, biosynthesis and function. Curr Opin Struct Biol 8, 558-564 (1998)

145. Manzi, A.E., Diaz, S., Varki, A.: High-Pressure liquid chromatography of sialic acids on a pellicular resin anion-exchange column with pulsed amperometric detection: A comparison with six other systems. Anal Biochem 188, 20 (1990)

146. Zanetta, J.-P., Pons, A., Iwersen, M., Mariller, C., Leroy, Y., Timmerman, P., Schauer, R.: Diversity of sialic acids revealed using gas chromatography/mass spectrometry of heptafluorobutyrate derivatives 10.1093/glycob/11.8.663. Glycobiology 11, 663-676 (2001)

147. Macher, B.A., Galili, U.: The Gal $\alpha 1,3 \mathrm{Gal} \beta 1,4 \mathrm{GlcNAc}-\mathrm{R}(\alpha-$ $\mathrm{Gal})$ epitope: a carbohydrate of unique evolution and clinical relevance. Biochim Biophys Acta 1780, 75-88 (2008). Epub 2007 Nov 2022

148. von Figura, K., Hasilik, A.: Lysosomal enzymes and their receptors. Annu Rev Biochem 55, 167-193 (1986)

149. Kornfeld, S.: Trafficking of lysosomal enzymes in normal and disease states. J Clin Invest 77, 1-6 (1986)

150. Ghosh, P., Dahms, N.M., Kornfeld, S.: Mannose 6-phosphate receptors: new twists in the tale. Nat Rev Mol Cell Biol 4, 202 $212(2003)$

151. Wilson, I.B.: Glycosylation of proteins in plants and invertebrates. Curr Opin Struct Biol 12, 569-577 (2002)

152. Zonneveld,d. Vries: Structure and function. Serine proteases and their serpin inhibitors in the nervous system. (1990)

153. Peter-Katalinic, J.: Methods in enzymology: O-glycosylation of proteins. Methods Enzymol 405, 139-171 (2005)

154. Harvey, D.J.: Structural determination of N-linked glycans by matrix-assisted laser desorption/ionization and electrospray ionization mass spectrometry. Proteomics 5, 1774-1786 (2005)

155. Dwek, R.A.: Glycobiology:\&nbsp; Toward Understanding the Function of Sugars. Chem Rev 96, 683-720 (1996)

156. Okafo, G., Burrow, L., Carr, S.A., Roberts, G.D., Johnson, W., Camilleri, P.: A coordinated high-performance liquid chromatographic, capillary electrophoretic, and mass spectrometric approach for the analysis of oligosaccharide mixtures derivatized with 2-aminoacridone. Anal Chem 68, 4424-4430 (1996)

157. Charlwood, J., Langridge, J., Tolson, D., Birrell, H., Camilleri, P.: Profiling of 2-aminoacridone derivatised glycans by electrospray ionization mass spectrometry. Rapid Commun Mass Spectrom 13, 107-112 (1999)

158. Charlwood, J., Langridge, J., Camilleri, P.: Structural characterisation of $\mathrm{N}$-linked glycan mixtures by precursor ion scanning and tandem mass spectrometric analysis. Rapid Commun Mass Spectrom 13, 1522-1530 (1999)

159. Qian, J., Liu, T., Yang, L., Daus, A., Crowley, R., Zhou, Q.: Structural characterization of N-linked oligosaccharides on monoclonal antibody cetuximab by the combination of orthogonal matrix-assisted laser desorption/ionization hybrid quadrupole-quadrupole time-of-flight tandem mass spectrometry and sequential enzymatic digestion. Anal Biochem 364, 8-18 (2007)

160. Brooks, S.A.: Appropriate glycosylation of recombinant proteins for human use: implications of choice of expression system. Mol Biotechnol 28, 241-255 (2004) 